\title{
Community-Based Approach in A Small Scale Irrigation Project in Indonesia: Ways and Advantages
}

\author{
Istijono, B. ${ }^{{ }^{*}}$ and Ophiyandri, T. ${ }^{1}$
}

\begin{abstract}
The implementation of community-based approach, where community can control a government owned infrastructure project, is rarely found. However, Sumatra River Basin Organization (BWSS) V successfully implemented a small scale irrigation project using this method in West Sumatra Province, Indonesia. This paper aims to describe how this policy was implemented, highlight its milestones, and discuss the advantages of its application. A detailed literature review and semi structured interviews were conducted to achieve the objectives. It was found that the implementation of community-based approach can bring about a sense of belonging, sustainability, and a source of income for the community. Hence, the project was finished on time within budget with high quality materials. In some cases the quantity of the project was more than it was targeted. The key policy that contributed to the success was trusting community to control the project and making sure that the proposed project came from the community.
\end{abstract}

Keywords: Community-based; small scale irrigation project; advantages; policy.

\section{Introduction}

In 2013, Directorate General of Water Resources, Ministry of Public Works of Indonesia, started implementing a project entitled 'Program for Acceleration and Development of Water Resources Infrastructure-Small Scale Irrigation' (Program Percepatan dan Perluasan Pembangunan Infrastruktur Sumber Daya Air di Irigasi Kecil/P4-ISDA-IK). This project was implemented in 28 provinces in Indonesia, including West Sumatera. In this province, it was managed by River Basin Organization of Sumatera V (Balai Wilayah Sungai Sumatera V/BWSS V). Unlike normal government owned projects which are usually constructed by contractors, P4-ISDA-IK project was designed to be carried out by community. Following the success of its implementation in 2013, the project was re-implemented in 2014.

The implementation of community-based programme is not always easy to accomplish. It is very popular as everybody tends to claim that his programme is a community-based project because it has involved community, no matter in which level the community participation is, Davidson et al. [1],

${ }^{1}$ Department of Civil Engineering, Andalas University, Л. Limau Manis, Kecamatan Pauh, Padang, INDONESIA

* Corresponding author; e-mail: bistijono1452@yahoo.co.id

Note: Discussion is expected before November $1^{\text {st }} 2015$, and will be published in the "Civil Engineering Dimension" volume 18, number 1, March 2016.

Received 12 July 2015; revised 29 August 2015; accepted 02 September 2015.
Dercon and Kusmawijaya [2], Jha et al. [3], and MacRae and Hodgkin [4] noted the problem in defining "community-based" programmes. In many cases, the concept of community-based programme is poorly defined. It is very interesting to find out whether the implementation of P4-ISDA-IK complies with the basic concept of community-based programme and what policy has been implemented. Further, this research also seeks to find the advantages of the project.

\section{Literature Review}

The word "community" has different meanings and definitions. Hillery in Kumar [5] mentioned that there were ninety-four different definitions of community in scientific literatures. All definitions use combinations of space, people, and social interactions. In this paper, community is defined as a group of farmers who utilize the water provided by irrigation system, and they are called the farmer water user group (Perkumpulan Petani Pemakai Air/P3A).

Arnstein [6] claimed that there were eight levels of citizen participation that he called 'A Ladder of Citizen Participation' (Figure 1). The bottom two levels of the eight-rung ladder are level 1, Manipulation and 2, Therapy, which describe the levels of non-participation, where power holders have the power to educate or cure the participants. Level 3, Informing, 4, Consultation, and 5, Placation, are levels of tokenism, where citizens may indeed hear, be heard, or give advice. Further up the ladder 
are levels of citizen power, level 6, Partnership, enables them to negotiate, 7, Delegated Power, and 8, Citizen Control. In these levels citizens obtain the majority of decision-making seats, or full managerial power. Arnstein's model has been modified by Choguill [7] to fit with underdeveloped countries. Choguill [7] classified the ladder of community participation into; neglect, rejection, manipulation, and support. Later on, Davidson et al. [1] combined these two theories to suit community participation in housing reconstruction projects (Figure 2).

Referring to the model of community participation proposed by Davidson et al [1], Ophiyandri et al [8] suggest that the definition of 'community-based' constitutes an approach where participation of the community is at the level of collaboration or empowerment. Figure 2 presents the minimum level of community participation to be named as 'community-based'. Hence, in this type of participation, the affected community is not just consulted about their needs and expectations, but they can be an owner, a supervisor, or even a contractor of their own reconstruction or rehabilitation project.

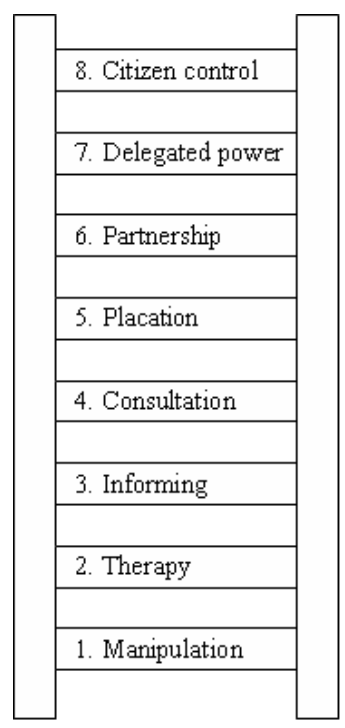

Figure 1. Eight Levels on the Ladder of Citizen Participation [6]

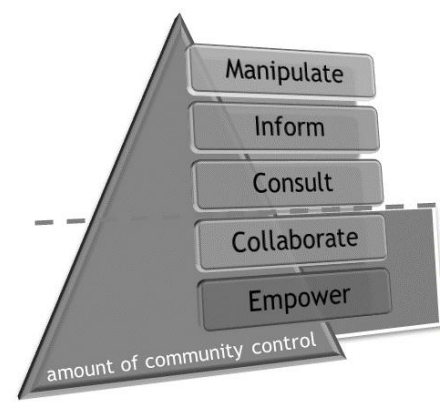

Figure 2. Minimum Level of Community Participation for a Community-Based Project [1]

\section{Method}

The research method adopted for this study is a case study as it can provide a deep analysis on the implementation of community-based method for a small scale irrigation program. This program was conducted in 2013 and 2014, and located in nine districts in West Sumatera, namely: Agam, Tanah Datar, Solok, Padang Pariaman, Pesisir Selatan, Pasaman Barat, Sijunjung, 50 Kota, and Bukittinggi.

The primary data were collected by conducting semistructured interviews with a government official (GOV), two consultants for P4-ISDA-IK (CON), two community facilitators (FAC), and nine communities in nine different project locations (COM) in 2014. Respondents were invited to answer questions dealing with how they perceived the advantages of the project, how communities selected the project location, and how communities carried out the project. Interviews with communities were conducted in the project locations, while others were conducted in Padang, the capital city of West Sumatra. Nine project locations in the first four regencies mentioned earlier were randomly selected as samples of this project. Nine samples for communities were adequate as no new information emerged after the first four interviews with them. Qualitative data analysis was carried out using NVivo 10 software [9].

The followings are the procedures in conducting the analysis using NVivo software. First, the raw data from the interviews are transcribed into text format using MsWord software. This data is then imported to NVivo. Prior to developing themes in NVivo, the preliminary themes and codes using the literature review and manual analysis on the transcripts are established. The theme is recognized as 'node' in NVivo. Finally, after developing the nodes, further analysis is conducted to the coded texts. Figure 3 shows the nodes utilized in this research that reflects the objectives of the study.

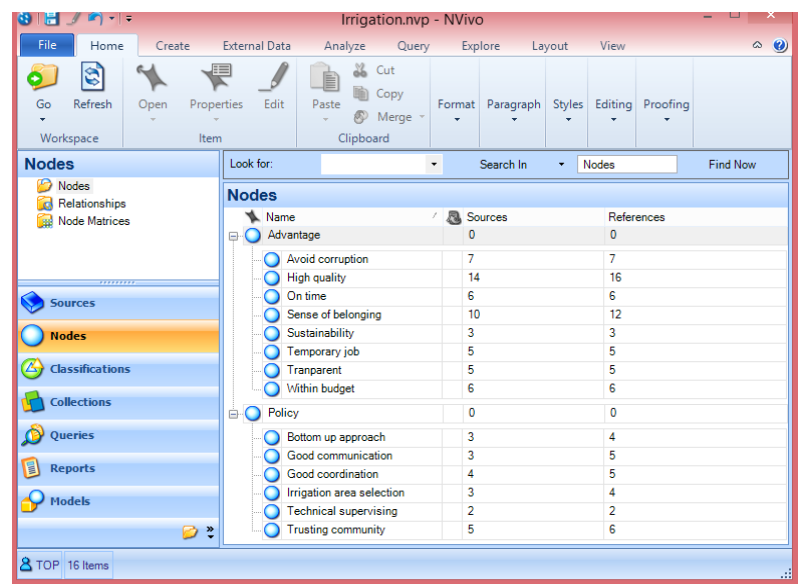

Figure 3. Nodes for Advantages and Policy of P4-ISDA-IK 


\section{Case Study}

The objective of P4-ISDA-IK program is to empower and encourage farmer's participation on the rehabilitation of small irrigation, and to carry out such rehabilitation. In this context, irrigation rehabilitation is defined as an activity to repair irrigation channel in order to restore its function and services. The activity may include: sediment lifting from canal, canal rehabilitation, and repair of diversion irrigation structures.

There are four principles in carrying out the P4ISDA-IK [10]:

1. Participative: community is given an opportunity to be actively involved in the project.

2. Transparent: budget utilisation has to be informed to all P3A members.

3. Accountable: accountability in time allocation, budget, and quality has to be performed

4. Sustainable: project outcomes have to be sustainnable.

The number of project carried out in 2013 is 195 projects. However, due to tight schedule at the end of fiscal year 2014 and tight budgeting policy from the government, the project locations has been reduced significantly to 30 locations in 2014. In both fiscal years, the total budget for each irrigation area was Rp 178 million. The allocation was Rp 2,5 million for preparation activities (meeting, survey, proposal preparation, report) and $\mathrm{Rp}$ 175,5 million for construction. Cost disbursement mechanism to community is as follows [10]: first disbursement is $40 \%$ of total budget after contract signing; second disbursement is $30 \%$ when construction progress is equal or more than $30 \%$; and final disbursement $(30 \%)$ is when construction progress is equal or more than $60 \%$. The payment is directly transferred to community account and can only be disbursed by bank when the check is signed by the head and treasurer of P3A.

There are some criteria for a village to be eligible for receiving funding: (1) it has a small irrigation (less than $1.000 \mathrm{ha}$ ), (2) its irrigation area is still productive and no significant land transformation, (3) majority of community members are farmers who rely on irrigation for rice plantation, and (4) it has a legal P3A.

\section{Policy}

There were four key stakeholders' involved in this project: BWSS V who owned the project, Water Resources Department at Regency level, facilitators, and P3A. BWSS was responsible for providing technical guidance for executing the project. The key policy taken by BWSS to ensure the success of this program is entrusting the community to carry out the project. The Community was trusted to define the location of the project and the most important thing is that the community can carry out the project independently. This policy is very important as BWSS put the community at the level of empowerment, the highest level of community participation. The Community was not just being consulted for what they want, but they were also empowered.

In the nine irrigation areas surveyed, all communities said that they all had a full control of the project. Eight P3As claimed that they did the rehabilitation project by their own resources. Figure 4 shows the community work together in carrying out the construction. Only in one location (Agam) the community had to hire workers from outside their village. In this area, none of the communities had skill in irrigation rehabilitation works and they also have other activities to earn money for their families. However, this community still had a great amount of control of the project, they acted as owners and supervisors.
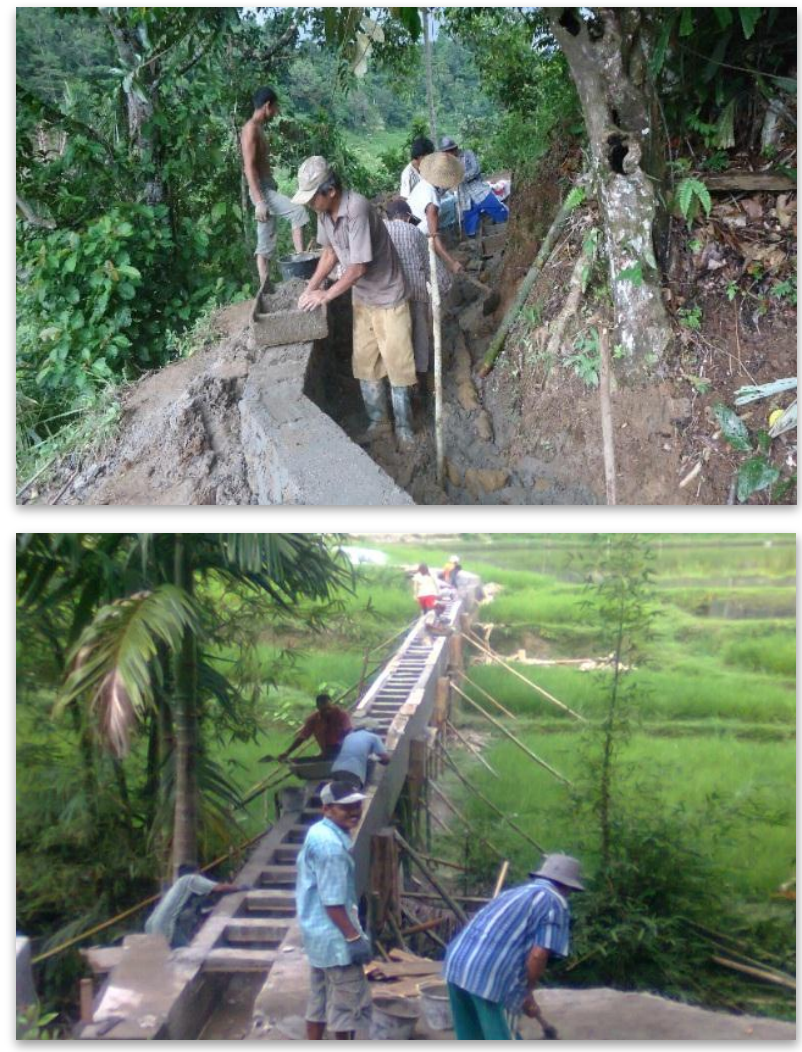

Figure 4. Community Acted as Labor in their Own Project

The second key stakeholder is government officials at Regency level. They acted as a liaison between BWSS V and the community. A BWSS official said that a good coordination between his organization and Regency organizations was one of the key 
successes of the project. He explained that this was because the Regency officials were the ones that really knew the condition of local irrigation area. So they could select which irrigation area was eligible to receive funding. They also proposed irrigation area by conducting a bottom up approach through a community meeting as can be seen in Figure 5 .

Facilitators who were recruited by BWSS V were the heart of this program. In total there were 79 facilitators in 2013 and 15 facilitators in 2014 respectively. Each facilitator was responsible for supervising two projects. The main task was to guide the community to construct the irrigation rehabilitation project. The facilitator helped the community from the early stage of the project (such as socialization, proposal preparation) until the project hand over.

P3A was a group who received fund from the government. In this program, P3As or communities were not positioned as the objects, but they were the actors, the ones who carried out the project. Some of them acted as an owner, a supervisor, or even a contractor of their own project. Their involvement was vital to the success of the programme. Before submitting a proposal to BWSS, the community selected which irrigation area they wanted to repair. Often it involved a lot of discussion among them. The Government through facilitators only facilitated the process, and did not interfere with the decision. As a result, the proposed area was purely the community's aspiration.

In the group, the community had to appoint a leader and a treasurer. Funding to construct the project was transferred directly by government to the tresurer's bank account, and could only be disbursed if it was approved by both of them. This process had helped government to avoid corruption and created transparency not only between government and community, but also between community leaders and its members.

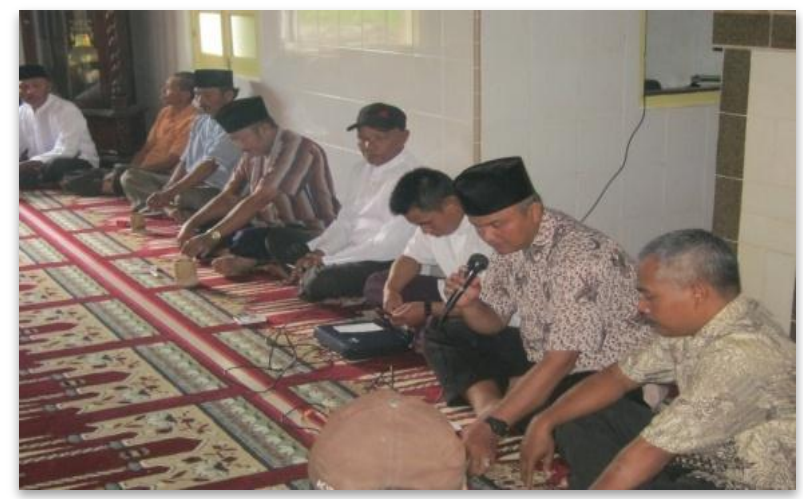

Figure 5. Community Meeting to Discuss the Proposed Location
The interviews suggest that communities had different method in communicating how much money had been disbursed for the project. For example, one community announced it by posting a piece of paper detailing the project disbursement in a small cafe or a mosque. While other community announced it every time its members had a meeting. Whatever the method adopted, the most important thing was that it was communicated to other member. So the trust between community members is established. In addition, BWSS highlighted that transparency was another key success factor for this project.

\section{Advantages}

The advantages of the implementation of community-based method for a small scale irrigation infrastructures project are enormous. The P4-ISDA-IK project is considered to be a huge success. In term of common objectives of construction project, where a project should be completed on time, within budget and with the desire quality, this project has successfully achieved it. BWSS V acknowledged this achievement and praised the community active participation in the project. First the project could be finished on time. GOV expressed:

In one location, although the funding disbursement was still 40\%, the project had completed 100\%. Do you know how they (community) did it? The community organization took material from the material shop by borrowing them. They showed their contract to the shop, and the store trusted the community will pay the debt once the community received the funding'.

As can be seen from Table 1, in 2013 although the budget spending for this project is less than 100\%, the average of physical realization is more than $100 \%(102.14 \%)$. It implies that the quantity achieved by the project is more than stated in the contract. This is something that was impossible to achieve under contractor-based project. COM1 said:

'(in the contract) our target for irrigation channel rehabilitation was 148 meter, and we delivered 164 meter. So there was 18 meter addition from the contract.'

There is an interesting question to be answered, how the community did this? The interviews reveal that there is no contribution in form of money from the community. The community achieves these milestones by contributing in different way. COM2 says:

We contribute by working hard. Sometimes we worked overtime for this project, and it did not have to be paid. The saving, we used it to buy materials'. 
Table 1. Budget and Physical Realization of P4-ISDA-IK Project

\begin{tabular}{|c|c|c|c|c|c|}
\hline \multirow[b]{2}{*}{ No } & \multirow[b]{2}{*}{ Regency } & \multicolumn{2}{|c|}{2013} & \multicolumn{2}{|c|}{2014} \\
\hline & & $\begin{array}{c}\text { Budget } \\
\text { realizati } \\
\text { on (\%) }\end{array}$ & $\begin{array}{l}\text { Physical } \\
\text { realization } \\
(\%)\end{array}$ & $\begin{array}{c}\text { Budget } \\
\text { realization } \\
(\%)\end{array}$ & $\begin{array}{c}\text { Physical } \\
\text { realizati } \\
\text { on (\%) }\end{array}$ \\
\hline 1 & Agam & 98.85 & 104.31 & 100.00 & 100.00 \\
\hline 2 & $\begin{array}{l}\text { Pesisir } \\
\text { Selatan }\end{array}$ & 96.06 & 101.96 & 100.00 & 100.00 \\
\hline 3 & Solok & 100.00 & 103.82 & 100.00 & 100.00 \\
\hline 4 & Tanah Datar & 98.85 & 100.00 & 100.00 & 100.00 \\
\hline 5 & Sijunjung & 97.93 & 100.00 & 100.00 & 100.00 \\
\hline $\begin{array}{l}6 \\
7\end{array}$ & $\begin{array}{l}\text { Pasaman } \\
\text { Barat } \\
\text { Padang }\end{array}$ & 100.00 & 101.97 & 100.00 & 100.00 \\
\hline & Pariaman & 98.76 & 102.92 & 100.00 & 100.00 \\
\hline & Average & 98.42 & 102.14 & 100.00 & 100.00 \\
\hline
\end{tabular}

Source: after [10] and [11]

COM3 gives another example:

'In one week, one day of our time working on the project was not paid. We got no objection with this, as the result of the project will benefited us. It looks like we worked to build our own house. Then, we used the extra money to buy materials from the shop'.

COM4 simply said that sometimes the community members worked together without paid (gotong royong) in the project.

However, in 2014 the budget realization is exactly the same as physical realization (100\%). According to $\mathrm{CON} 1$, this is due to government administration requirements. Although in some locations the physical realizations are higher than $100 \%$, it has to be noted as $100 \%$.

Secondly, the quality of the project is also high. All interviews with communities stated that they feel that they owned this project. So they tried so hard that they can deliver the best quality. Majority of them compared their achievement to the project that they have witnessed carried out by a contractor. COM2 said

If this project was carried out by a contractor, I believed the quality won't be this good. The composition of cement and sand for our (irrigation) lining was 1:2. Contractor might do it for 1:5.'

The community supervised the project carefully. In this case, this project successfully established the sense of belonging of community to the project. The sense of belonging also can create sustainability of the project. The community will care something that they built by their own.

One other distinct advantage of this project is it provides a temporary job opportunity for community.
Community or P3A member that worked as labor or worker for the project will be paid.

\section{Conclusions}

The implementation of community-based approach in small scale irrigation infrastructures project is a great success. The policy implemented by trusting the community to have a full control of the project and by ensuring that the proposed irrigation area to be rehabilitated coming from them contributed to the success of this program. As community was empowered, which is the highest level of community participation, the project has successfully implemented the concept of community-based approach. The advantage of this project is the project can be finished on time, within budget and using high quality materials. In some cases the quantity of the project is more than targeted, higher than $100 \%$. Other distinct advantage is this project can create a sense of belonging and can ensure the sustainability. The project also acted as a temporary source of income for the community.

\section{References}

1. Davidson, C.H., Johnson, C., Lizarralde, G., Dikmen, N., and Sliwinski, A., Truths and Myths about Community Participation in Postdisaster Housing Projects, Habitat International, 31, 2007, pp. 100-115.

2. Dercon, B. and Kusumawijaya, M., Two Years of Settlement Recovery in Aceh and Nias: What should the Planners have Learned?, 43rd ISOCARP Congress, Antwerp, Belgium, September 19-23, 2007.

3. Jha, A. K., Barenstein, J. D., Phelps, P. M., Pittet, D., and Sena, S., Safer Homes, Stronger Communities: A Handbook for Reconstructing after Natural Disasters, Washington: The World Bank, 2010.

4. MacRae, G. and Hodgkin, D., Half Full or Half Empty? Shelter after the Jogjakarta Earthquake, Disasters, 35(1), 2011, pp. 243-267.

5. Kumar, C., Revisiting 'Community' in Community-based Natural Resource Management, Community Development Journal, 40(3), 2005, pp. 275-285.

6. Choguill, M.B.G., A Ladder of Community Participation for Underdeveloped Countries, Habitat International, 20(3), 1996, pp. 431-444.

7. Arnstein, S.R., A Ladder of Citizen Participation, Journal of the American Institute of Planners, 35(4), 1969, pp. 216-224.

8. Ophiyandri, T., Amaratunga, D., and Pathirage, C., Community Based Post Disaster Housing Reconstruction: Indonesian Perspective, Procee- 
Istijono, B. et al. / Community-Based Approach in A Small Scale Irrigation Project/ CED, Vol. 17, No. 2, September 2015, pp. 95-100

ding of CIB World Congress, Salford, United Kingdom, May 10-13, 2010.

9. QSR International (2015) NVivo 10 for Windows, available at www.qsrinternational.com/ products_nvivo.aspx, accessed on 30 August 2015.
10. BWSS V, Technical Guidance: Program for Acceleration and Development of Water Resources Infrastructure-Small Scale Irrigation (P4ISDA-IK), Sumatera River Basin Organization V (BWSS V), 2014.

11. BWSS V, Final Report: P4-ISDA-IK. Sumatera River Basin Organization V(BWSS V), 2015. 